\title{
Maize Seed Contamination and Seed Transmission of Maize Chlorotic Mottle Virus in Kenya
}

\author{
Esther N. Kimani, ${ }^{1,2,+}$ Samuel M. Kiarie, ${ }^{3}$ Cyrus Micheni, ${ }^{3}$ Laureen G. Muriki, ${ }^{3}$ Douglas W. Miano, ${ }^{2}$ Isaac Macharia, ${ }^{4}$ \\ Gary P. Munkvold, ${ }^{5}$ William M. Muiru, ${ }^{2}$ B. M. Prasanna, ${ }^{6,+}$ and Anne Wangai ${ }^{3,6}$ \\ ${ }^{1}$ Crop Biotechnology, Kabete Center, Biotechnology Research Institute, Kenya Agricultural and Livestock Research Organization (KALRO), \\ Nairobi, Kenya \\ ${ }^{2}$ Department of Plant Science and Crop Protection, University of Nairobi, Kangemi, Nairobi, Kenya \\ ${ }^{3}$ Plant Pathology Department, Kabete Center, Food Crops Research Institute, Kenya Agricultural and Livestock Research Organization (KALRO), \\ Nairobi, Kenya \\ ${ }^{4}$ Kenya Plant Health Inspectorate Services (KEPHIS), Nairobi, Kenya \\ ${ }^{5}$ Department of Plant Pathology and Microbiology, Seed Science Center, lowa State University, Ames, IA, 50011-1050, U.S.A. \\ ${ }^{6}$ Global Maize Program, International Maize and Wheat Improvement Center (CIMMYT), ICRAF House, United Nations Avenue - Gigiri, \\ Nairobi, Kenya
}

Accepted for publication 23 June 2021.

\section{Abstract}

Maize chlorotic mottle virus (MCMV) causes maize lethal necrosis disease in combination with a cereal-infecting potyvirus, leading to high yield losses. There is limited information on seed infection or contamination rate by MCMV and its comparison with transmission rate to maize seedlings. This study was conducted to determine the extent of seed contamination in seed lots from MCMV-infected maize fields in Kenya and the transmission of MCMV from seeds to seedlings. To determine the contamination levels, whole seeds were ground and the extract tested for the presence of MCMV using double antibody sandwich enzymelinked immunosorbent assay (DAS-ELISA). Seedling grow-outs were tested for seed transmission of MCMV using DAS-ELISA and real-time reverse transcription polymerase chain reaction (realtime RT-PCR) methods. The seed contamination rates of the four seed lots tested ranged from 4.9 to $15.9 \%$. MCMV transmission frequency for 37,617 seedlings, tested in 820 pools of varying seed amounts by DAS-ELISA, was $0.17 \%$, whereas a transmission frequency of $0.025 \%$ was obtained from 8,322 seedlings tested in 242 pools by real-time RT-PCR. Seeds from plants mechanically inoculated with MCMV had an overall seed transmission rate of $0.04 \%$ in 7,846 seedlings tested in 197 pools. The study showed that even with substantial contamination of maize seed with MCMV, the transmission of the virus from the seed to seedlings was low. Nevertheless, even low rates of transmission can be significant under field conditions where insect vectors can further spread the disease from infected seedlings, unless diseased plants are detected in time and properly managed.

Keywords: maize lethal necrosis, maize chlorotic mottle virus, seed contamination, seed transmission
Maize has the highest production among the cereal crops globally and is the important cereal in Latin America and sub-Saharan Africa (Ranum et al. 2014). In Kenya, maize is the main staple food; the crop had an average annual production of 3.57 million

Corresponding authors: E. N. Kimani; esther.kimani@gmail.com and B. M. Prasanna; b.m.prasanna@cgiar.org

Current address for Anne Wangai: P.O. Box 9369-00100, Nairobi, Kenya.

Funding: This work was supported by a subgrant under a project led by the International Maize and Wheat Improvement Center (CIMMYT) and funded by Bill and Melinda Gates Foundation (INV-006697/OPP1138693), and the CGIAR Research Program on Maize (MAIZE). MAIZE receives Windows 1 and 2 support from the Governments of Australia, Belgium, Canada, China, France, India, Japan, Korea, Mexico, the Netherlands, New Zealand, Norway, Sweden, Switzerland, the United Kingdom, the United States, and the World Bank. USDA 2017 Norman E. Borlaug International Agricultural Science and Technology Fellowship funded the travel and work of the first author at the Iowa State University, U.S.A.

The author(s) declare no conflict of interest.

Copyright (c) 2021 The Author(s). This is an open access article distributed under the CC BY 4.0 International license. metric tons in the years 2014 to 2018 (FAOSTAT 2021), with an average consumption of $67.3 \mathrm{~kg} /$ person in 2019 (KNBS 2020). Since 2011, when the maize lethal necrosis (MLN) disease was first reported in Kenya (Wangai et al. 2012), maize production in the country has been threatened by MLN, which was estimated to have caused crop losses of 0.5 million tons in 2013 (De Groote et al. 2016). An increase in maize chlorotic mottle virus (MCMV) incidence has been reported in Kenya, Uganda, and Ethiopia in 2018-2019 (Prasanna et al. 2020). MLN is a result of infection of maize plants by MCMV in combination with maize-infecting potyvirids, such as sugarcane mosaic virus (SCMV), maize dwarf mosaic virus (MDMV), Johnson grass mosaic virus in the genus Potyvirus, or wheat streak mosaic virus in the genus Tritimovirus (Goldberg and Brakke 1987; Stewart et al. 2017; Uyemoto et al. 1980; Wangai et al. 2012).

Maize chlorotic mottle virus is the sole member of the genus Machlomovirus, in the family Tombusviridae. Globally, MCMV was first reported in the 1970s in Peru and subsequently in different parts of the world, including eastern Africa (Prasanna et al. 2020; Redinbaugh and Stewart 2018). The genome sequence of the MCMV-Kenya isolate is $99 \%$ identical to that in Rwanda 
(Adams et al. 2014), has 98 to $99 \%$ similarity to MCMV isolates from China (Adams et al. 2013), and is 96 to $97 \%$ identical to the MCMV isolates from Kansas and Nebraska in the United States (Adams et al. 2013; Wamaitha et al. 2018). The virus is transmitted through vectors, including corn thrips (Frankliniella williamsi), maize rootworms (Diabrotica undecimpunctata, Diabrotica longicornis, and Diabrotica virgifera), cereal leaf beetles (Oulema melanopus), and flea beetles (Systena frontalis and Chaetocnema pulicaria) (Cabanas et al. 2013; Jensen 1985; Jiang et al. 1992). Transmission is also reported to be through seed and soil, as well as mechanically by contaminated farm implements (Mahuku et al. 2015; Nelson et al. 2011).

Seed transmission of MCMV was reported from a study conducted on 25 seed lots in Hawaii with a transmission rate of 0 to $0.33 \%$ (Jensen et al. 1991), whereas another study reported no seed transmission (Bockelman et al. 1982). Testing of 25 individual seeds obtained from MCMV-infected maize plants in Kenya resulted in $72 \%$ of the seeds being positive for MCMV (Mahuku et al. 2015). None of the earlier studies attempted to comprehensively determine the possibility of seed contamination leading to transmission of MCMV to next-generation seedlings using a large sample size. The present study was therefore undertaken to evaluate the extent of contamination of seed lots by MCMV and further transmission of the East African isolate of MCMV to the grown-out seedlings.

\section{Experimental Material}

Commercial maize seed lots harvested in 2015 and 2017 from the Western region of Kenya, designated as seed lots K27, K4, A, and B (Table 1), were contributed by a seed company. These seed lots from commercial hybrid seed production fields were rejected by the Kenya Plant Health Inspectorate Services (KEPHIS) after laboratory testing, due to detection of MCMV. In Kenya, seed production fields are regularly inspected by KEPHIS for possible presence of MLN three times prior to maturity, and laboratory testing is carried out on pooled samples of 7-day-old seedlings (two-leaf stage), using real-time reverse transcription polymerase chain reaction (real-time RT-PCR) (Shango et al. 2019). The four seed lots were sampled according to International Seed Testing Association guidelines (ISTA 2016) for studying the levels of contamination and seed transmission of MCMV. The cultivars of the seed lots were different except for lots $\mathrm{K} 4$ and B. Group testing of the samples in pools was adopted (Albrechtsen 2006a) to reduce the cost of laboratory analysis per sample. Further studies on seed transmission were carried out using seeds from maize plants (hybrid maize cultivars H614, DK777, and DUMA 43) mechanically inoculated with MCMV at Kenya Agricultural and Livestock Research Organization (KALRO)-Njoro quarantine field. H614 and DUMA 43 are highly susceptible to MCMV, and DK777 is partially resistant to MLN (having a score of 5.0 on a scale of 1 to 9 ).
The work was done at the Molecular Pathology Laboratory at KALRO, Food Crops Research Institute-Kabete Center in Kenya (KALRO-Kabete). Seed contamination of seed lots K4 and K27 was tested at the Seed Science Center, Iowa State University, Ames, IA, U.S.A.

\section{Testing of Maize Seed for Contamination with MCMV}

Whole maize seeds were sampled from the four seed lots. The samples obtained were then grouped into pools of 20 seeds each for lots $\mathrm{A}$ and $\mathrm{B}$, and tests were carried out at KALRO-Kabete, Kenya; the pools were 50 seeds each for lots K27 and K4, and the tests were carried out at Iowa State University, Ames, IA, U.S.A. Whole seed pools were then ground to a coarse texture for MCMV testing. The total number of seeds tested for the four seed lots was 4,560, 3,860, 1,850, and 3,100 for lots A, B, K27, and $\mathrm{K} 4$, respectively. An IKA Tube Mill control grinder (Tube Mill CS000, IKA, Staufen, Germany) was used for grinding the pools of 20 dry seeds, whereas a Waring 7011HS blender (Waring Commercial, Stamford, CT) was used to grind the pools of 50 seeds in enzyme-linked immunosorbent assay (ELISA) general extraction buffer.

Double antibody sandwich ELISA (DAS-ELISA) was used to detect MCMV. Antibodies developed against MCMV were coated on a high protein-binding capacity polystyrene 96-well flatbottomed microplate (F96 Maxisorp, Nunc, Thermo Fisher Scientific, Waltham, MA). The samples from seed lots K27 (37 subsamples) and K4 (62 subsamples) were tested using a commercial ELISA reagent set for MCMV (Agdia, Elkhart, IN), following the manufacturer's instructions. The general extraction buffer was prepared in the laboratory using $0.2 \%$ chicken egg albumin, $0.13 \%$ sodium sulfite, and $2 \%$ polyvinylpyrrolidone (SigmaAldrich, St. Louis, MO) in $1 \times$ phosphate-buffered saline with Tween (PBST). The buffer was added to the seed (ratio of 1:1) and the mixture shaken by hand vigorously prior to soaking overnight in a conical flask and grinding the next day. Each sample was replicated twice on the plate. The optical density absorbance values were measured using a microplate spectrophotometer (PowerWave HT, BioTek Instruments, Winooski, VT) at wavelength of $405 \mathrm{~nm} 1 \mathrm{~h}$ after incubation at room temperature. The controls included in all the microplates were two negative controls (general extraction buffer and MCMV-free maize seed [20 seeds ground together] obtained from the Seed Science Center, Iowa State University, U.S.A.) and a positive control (maize seed from MCMV-infected plants obtained from the MLN screenhouse at KALRO-Kabete, Kenya).

DAS-ELISA was carried out on samples from seed lots A and $B$ at KALRO-Kabete, using MCMV antibodies obtained from Plant Pathology Department, University of Minnesota, U.S.A. The DAS-ELISA procedure was similar to that of the Agdia ELISA reagent set for MCMV with slight modifications, and the buffers were prepared in the laboratory with similar chemical composition. The plates were incubated at $37^{\circ} \mathrm{C}$ for $1 \mathrm{~h}$, except

\begin{tabular}{|c|c|c|c|c|}
\hline \multicolumn{5}{|c|}{$\begin{array}{c}\text { TABLE } 1 \\
\text { Details of the seed lots used in the study }\end{array}$} \\
\hline Parameter & Lot A & Lot B & Lot K27 & Lot K4 \\
\hline Sampling date & 2018 & 2018 & 2017 & 2017 \\
\hline Source of seed & Blended, rainfed fields & Blended, irrigated fields & Single, rainfed field & Blended, rainfed fields \\
\hline
\end{tabular}


the substrate step, which was incubated at room temperature for $1 \mathrm{~h}$. The primary antibodies were diluted at a ratio of $1: 1,000$ in carbonate buffer, whereas the alkaline phosphatase conjugated antibody was diluted at a ratio of 1:4,000 in enzyme conjugate buffer (buffer composition similar as those of Agdia). The optical density absorbance values of the reaction were measured using a microplate reader (Elx808 BioTek Instruments) at a wavelength of $405 \mathrm{~nm}, 1 \mathrm{~h}$ after incubation at ambient temperature. Similar controls as those described above were used in all the microplates. The MCMV-free maize seed was obtained from a seed company and tested for confirmation.

Samples from both experiments with an average optical absorbance value from the two replicates that was higher than twice that of the negative maize seed control and extraction buffer were considered positive for MCMV. Data were collected on the number of samples that were positive and negative for MCMV. The most probable percentage of infected seeds was calculated using a binomial statistical method formula at $95 \%$ confidence level (Chen and Swallow 1990):

$$
P=\left[1-(Y / N)^{1 / n}\right] \times 100
$$

where $n$ is the number of seeds per group sample, $N$ is the number of groups, and $Y$ is the assay-negative groups.

\section{Detection of MCMV in Seedling Grow-Outs from Commer- cial Seed Contaminated with MCMV}

Seed to seedling transmission of MCMV was tested by germinating seeds from the four seed lots (Table 1) by planting the sampled seeds and from the healthy certified seed (DK777) in trays filled with vermiculite mixed with sterile soil at a ratio of $1: 2$, at KALRO-Kabete, in a seed laboratory, at average day room temperature of $21^{\circ} \mathrm{C}$, with an average of $12 \mathrm{~h}$ light and $12 \mathrm{~h}$ night. Fifty seeds were sown in each tray, and leaves from germinated seedlings from each tray were sampled 10 days after planting (at two-leaf stage) (Shango et al. 2019). Insecticides were sprayed weekly to control possible insect vectors transmitting MCMV. Seedlings at the two-leaf stage were counted, recorded, and sampled into one sample bag as one pooled sample. Contamination of samples was controlled by handling the seedlings on each tray with a clean set of gloves. The samples were transported to the laboratory in a cool box and stored at $-40^{\circ} \mathrm{C}$. Testing was carried out using DAS-ELISA with MCMV antibodies (from the University of Minnesota) as described above.

A total of 37,617 seedlings from the four seed lots (Table 2) were tested using DAS-ELISA in 820 pools with a varying number of seedlings from each tray, ranging from seven to 50

\begin{tabular}{|c|c|c|c|}
\hline \multicolumn{4}{|c|}{$\begin{array}{l}\text { TABLE } 2 \\
\text { DAS-ELISA-based detection of maize chlorotic mottle virus } \\
\text { (MCMV)-contaminated maize in seedlings grown from } \\
\text { MCMV seed lots }\end{array}$} \\
\hline $\begin{array}{l}\text { Seed } \\
\text { lot }\end{array}$ & $\begin{array}{l}\text { No. of } \\
\text { seedlings } \\
\text { tested }\end{array}$ & $\begin{array}{l}\text { No. of positive } \\
\text { pools }{ }^{\mathrm{a} / \text { total }} \\
\text { no. of pools } \\
\text { tested }\end{array}$ & $\begin{array}{c}\text { Estimated seed } \\
\text { transmission } \\
\text { rate }\end{array}$ \\
\hline A & 17,098 & $15 / 360$ & $0.09 \%$ \\
\hline B & 15,319 & $4 / 356$ & $0.03 \%$ \\
\hline K27 & 4,800 & $0 / 96$ & 0 \\
\hline K4 & 400 & $2 / 8$ & $0.57 \%$ \\
\hline
\end{tabular}

${ }^{\text {a }}$ Samples were tested in pools with varying pool sizes. depending on germination count during sampling. The samples were crushed using a tissue homogenizer and sample mesh bag (Agdia) in general extraction buffer as described above, at a ratio of 1:10 (w/v). Three controls were included in each plate: two negative controls (general extraction buffer and leaf sample from healthy certified seed) and one MCMV-positive leaf from maize plants infected with MCMV (maintained at Biosafety Greenhouse, KALRO-Kabete, Kenya).

\section{Detection in Seedling Grow-Outs by Real-Time RT-PCR}

Seedlings from seed lots A and B were also tested using realtime RT-PCR. RNA was extracted from leaves of 8,322 seedlings, which were in 242 pools, using a CTAB modified protocol (Monger et al. 2001). The pool sizes had samples from a range of 14 to 50 seedlings. Real-time RT-PCR was carried out using MCMV primers designed from the coat protein of MCMV (Liu et al. 2016): forward primer 5'-GAGTCCTGCCAATCCAAAG TG-3', reverse primer 5'-TGGGTGGGTCAAGGCTTACTA-3', and probe 5'-FAM-AGCCGCCGCCCACTCTCCAG-BHQ-3'. The PCR mix consisted of $0.5 \mu \mathrm{l}$ of forward and reverse primers, $0.3 \mu \mathrm{l}$ of fluorescence-labeled probe, $2 \mu \mathrm{l}$ of RNA template, $1.4 \mu \mathrm{l}$ of diethyl pyrocarbonate-treated water, and SensiFAST Probe Hi-Rox one-step kit (BIO 77001, Bioline USA, Taunton, MA) components comprising $0.2 \mu \mathrm{l}$ of RNase inhibitor, $0.1 \mu \mathrm{l}$ of reverse transcription, and $5 \mu \mathrm{l}$ of SensiFAST probe Hi-Rox one-step buffer (with Hot Start DNA polymerase). The reaction was done in a real-time PCR equipment (StepOnePlus, Applied Biosystems, Thermo Fisher Scientific) with the following cycling conditions: complementary strand synthesis step at $50^{\circ} \mathrm{C}$ for $10 \mathrm{~min}, 95^{\circ} \mathrm{C}$ for $1 \mathrm{~min}$, and then 40 cycles of $94^{\circ} \mathrm{C}$ for $10 \mathrm{~s}$ and $60^{\circ} \mathrm{C}$ for $1 \mathrm{~min}$. Data collected was the threshold cycle $(\mathrm{Ct})$ value. Samples that had $\mathrm{Ct}$ values lower than the $\mathrm{Ct}$ values of the negative controls (healthy maize leaf sample and nontemplate reaction) were considered positive for MCMV.

Seed transmission for each of the pooled samples from the four seed lots, based on DAS-ELISA and real-time RT-PCR methods, was calculated using the pooled prevalence tests using Epitools epidemiological calculators (Sergeant 2018) applying a maximum-likelihood estimate of prevalence of the virus for the pooled samples. In this case, we applied the variable pool sizes and perfect test (Sergeant 2018), using the data for each pool size, number of pools in the pool size, and number of positive pools per size for each of the seed lots. The fixed pool size and perfect test method were applied where the pool sizes were the same in the seed lot. The prevalence of the virus was obtained at a $95 \%$ confidence interval and the seed transmission reported as a percentage.

\section{Detection of MCMV from Seedling Grow-Outs Germinated from Seeds from Mechanically Inoculated Plants}

One hundred sixty-five plants from three hybrid cultivars each (H614, DK777, and DUMA 43) were mechanically inoculated with MCMV at the four-leaf stage at KALRO-Njoro quarantine field in 2017 and 2018. MCMV inoculum was obtained at the KALRO biosafety level II greenhouse, where the MCMVinfected plants were grown under controlled conditions for research use. Leaves from the MCMV-infected plants were blended with $0.1 \mathrm{M}$ phosphate buffer at a ratio of 1:10 (weight/ volume). The mixture was sieved using a muslin cloth, and carborundum was added just before inoculation. A motorized sprayer 
was used to apply the inoculum on the seedlings. MCMV insect vectors and fall armyworm (Spodoptera frugiperda) were controlled by spraying insecticides weekly by alternating alphacypermethrin (Alphaguard 10EC) and chlorpyrifos (Pyrinex 48EC) combined with either chlorantraniliprole and abamectin (Voliam Targo) or emamectin benzoate (Escort 19EC).

The seeds from the infected maize plants were harvested at maturity and dried to a moisture content of $13 \%$ before storage. Three hundred seeds for each cultivar were directly tested by DAS-ELISA in group sizes of 20 seeds each, and MCMV was detected from $98 \%$ of the replicated samples. The harvested seeds were planted and treated as in the previously described seed transmission experiments for commercial seed lots; 7,846 grow-out seedlings were tested for presence of MCMV using the DAS-ELISA method, in pool sizes ranging from 20 to 50 seedlings. The data on the number of positive pools and the number of pools tested per pool size were analyzed as described above using the Epitools epidemiological calculators variable pool sizes and perfect test (Sergeant 2018).

\section{Extent of Contamination of the Commercial Seed Lots by MCMV}

The four naturally contaminated seed lots (A, B, K4, and K27) were found to be contaminated by MCMV at varying levels. The average contamination rate for the four seed lots was $8.75 \%$, with a range of $4.90 \%$ (K27) to $15.93 \%$ (B) (Table 3) at a $95 \%$ confidence level.

\section{Seed Transmission of MCMV from Commercial Seed Contaminated with MCMV to Seedlings}

The results from the total number of pooled samples tested using DAS-ELISA indicated that 21 pooled samples tested positive for MCMV out of a total of 820 pooled samples analyzed in the study (Table 2). The numbers of pools that were found positive for MCMV were 15 from lot A, four from lot B, and two from lot K4. A total of 37,617 seedlings were tested from the four seed lots. The average seed transmission rate for the four seed lots was $0.17 \%$ (Table 2) when tested using DAS-ELISA. The four seed lots had varying seed transmission rates, with lot K4 having the lowest number of samples tested (400) but recording the highest seed transmission rate $(0.57 \%)$.

Transmission of MCMV from the contaminated seed of seed lots $\mathrm{A}$ and $\mathrm{B}$ to the next-generation seedlings was analyzed using the real-time RT-PCR method. Only two composite samples were found to be positive for MCMV (Table 4), with $\mathrm{Ct}$ values lower than those of the negative healthy control, which ranged from 29.94 to 34.04 for different plates. The average seed transmission of MCMV for the seed lots tested by real-time RT-PCR was $0.025 \%$. These two samples that tested positive for MCMV in real-time RT-PCR were both negative when tested using DAS-ELISA, reflecting the sensitivity of real-time RT-PCR in detection of a small amount of viruses in samples (Liu et al. 2016). However, in this study, the high cost of detection by realtime RT-PCR limited its use on all the samples that were tested using the DAS-ELISA method.

\section{Transmission of MCMV from Seeds Obtained from Plants Mechanically Inoculated with MCMV}

Three seedling pools obtained from seeds that were mechanically inoculated with MCMV tested positive. These were from the seeds of DK777 (one pool) and H614 (two pools) harvested in 2017 (Table 5). There was no detection of MCMV in the samples from 2018. Seed transmission rates of 0.1 and $0 \%$ were calculated from the infected plants harvested in $2017(2,944$ seedlings) and 2018 (4,902 seedlings), respectively. Based on the data from this study, an average seed transmission rate of $0.04 \%$ was calculated.

Seed transmission of viruses occurs when the virus is passed from the contaminated seed to the seedling grown out during the process of germination and growth. In most such cases, seed transmission occurs when there is invasion of the embryo

\begin{tabular}{|c|c|c|c|}
\hline \multicolumn{4}{|c|}{$\begin{array}{c}\text { TABLE } 4 \\
\text { Seed transmission of maize chlorotic mottle virus in } \\
\text { seedlings germinated from contaminated seeds, as tested } \\
\text { using real-time RT-PCR }\end{array}$} \\
\hline $\begin{array}{l}\text { Seed } \\
\text { lot }\end{array}$ & $\begin{array}{l}\text { No. of } \\
\text { seedlings } \\
\text { tested }\end{array}$ & $\begin{array}{l}\text { No. of positive } \\
\text { sample pools/no. } \\
\text { of pools tested }\end{array}$ & $\begin{array}{l}\text { Minimum seed } \\
\text { transmission rate }\end{array}$ \\
\hline A & 4,837 & $1 / 143$ & $0.02 \%$ \\
\hline B & 3,485 & $1 / 99$ & $0.03 \%$ \\
\hline
\end{tabular}

\section{TABLE 5}

Data on the number of seedlings tested for each cultivar and the number of pools that tested positive for maize chlorotic mottle virus by DAS-ELISA

\begin{tabular}{lccccc} 
& \multicolumn{2}{c}{$\mathbf{2 0 1 7}$} & & \multicolumn{2}{c}{2018} \\
\cline { 2 - 3 } \cline { 5 - 6 } Cultivar & $\begin{array}{c}\text { Seedlings } \\
\text { tested }\end{array}$ & $\begin{array}{c}\text { Positive } \\
\text { pools }^{\mathbf{a}}\end{array}$ & & $\begin{array}{c}\text { Seedlings } \\
\text { tested }\end{array}$ & $\begin{array}{c}\text { Positive } \\
\text { pools }^{\mathbf{a}}\end{array}$ \\
\hline DK777 & 1,031 & $1^{\mathrm{b}}$ & & 1,640 & 0 \\
DUMA 43 & 796 & 0 & & 1,630 & 0 \\
H614 & 1,117 & $2^{\mathrm{b}}$ & & 1,632 & 0 \\
\hline
\end{tabular}

${ }^{\text {a }}$ Pool sizes varied from 20 to 50 seedlings.

${ }^{\mathrm{b}}$ The positive pools had 50 seedlings each.

\begin{tabular}{|c|c|c|c|c|}
\hline \multicolumn{5}{|c|}{$\begin{array}{l}\text { TABLE } 3 \\
\text { DAS-ELISA-based estimation of percentage of maize chlorotic mottle virus (MCMV) contamination in the four maize seed lots }\end{array}$} \\
\hline Seed lot & $\begin{array}{l}\text { Total number of } \\
\text { seeds tested }\end{array}$ & $\begin{array}{l}\text { Number of MCMV+ seed } \\
\text { pools }{ }^{2} / \text { total number of } \\
\text { seed pools tested }\end{array}$ & $\begin{array}{c}\text { Proportion of } \\
\text { positive samples }\end{array}$ & $\begin{array}{l}\text { Calculated } \% \text { MCMV } \\
\text { contamination rate }^{b}\end{array}$ \\
\hline A & 4,560 & $165 / 228$ & 0.72 & $6.23 \%$ \\
\hline B & 3,860 & $187 / 193$ & 0.96 & $15.93 \%$ \\
\hline K27 & 1,850 & $34 / 37$ & 0.92 & $4.90 \%$ \\
\hline
\end{tabular}

\footnotetext{
${ }^{a}$ Samples were tested in pools, with a pool size of 20 seeds for lots A and B and 50 seeds for lots K27 and K4.
}

${ }^{\mathrm{b}}$ Contamination rate was calculated using a binomial statistical method, $95 \%$ confidence level. 
(Johansen et al. 1994; Sastry 2013a). In other cases, although the virus may not be present in the embryo, contamination of the seed coat or presence of virus in the outer layers of the endosperm can lead to external seed transmission (Bernardo et al. 2018; Sastry 2013a), such as for cucumber green mottle mosaic virus in watermelon (Sui et al. 2019). The virus, whether inactivated or viable, can be detected by microscope, serological, and nucleic-acid based methods. Results from the present study showed that seeds sampled from commercial hybrid maize seed lots in Kenya were contaminated with MCMV at varying levels ranging from 4.9 to $15.93 \%$. The previously reported contamination rate from 260 maize seeds obtained from 26 seed lots in Kenyan markets was 6\%; MCMV was detected in 12 of the 26 seed lots (Mahuku et al. 2015). This was within the same range of the findings in this study with an average contamination rate of $8.75 \%$. These levels of seed contamination by a virus are relatively low, compared with virus contamination in vegetables, fruits, and legumes; for example, contamination could be as high as 100 and $93.85 \%$ by cucumber green mottle mosaic virus in watermelon and melon seeds, respectively (Wu et al. 2010). Virus contamination detected in whole seeds by serological and nucleic acid-based methods may include viable, transmissible virus in the embryo as well as inactivated virus found externally or in various seed tissues (Albrechtsen 2006b; Crowley 1957). Virus inactivation can occur during seed maturation and also during storage of the seeds (Dombrovsky and Smith 2017). The testing of whole seeds for viruses in most cases does not give a clear indication of the risk of seed transmission into seedlings (Johansen et al. 1994).

In the present study, seed transmission of MCMV when tested using DAS-ELISA ranged from 0 to $0.57 \%$ for samples collected from commercial seed lots and from 0 to $0.01 \%$ for samples from maize plants of three cultivars (DK777, H614, and DUMA 43) that were mechanically inoculated with MCMV. The location of the virus in seed tissues was not determined; therefore, it is uncertain whether seed transmission resulted from external contamination or internal infection. Jensen et al. (1991) reported MCMV transmission rates from maize seeds obtained from four seed lots in the United States as $0.03,0.067,0.2$, and $0.33 \%$, respectively, from about 42,000 seedlings, whereas no seed transmission of MCMV was revealed from 2,153 maize inbred seedlings and 1,898 hybrid seedlings (Bockelman et al. 1982). In another study, analysis of seeds from MCMV-infected maize inbred lines (24) in Kenya revealed seed transmission in one pooled sample from a total of 480 seedlings (Kitira 2018). From these studies reported, it is evident that the transmission of MCMV through seed is consistently lower than $1 \%$. Low seed transmission rates have also been documented for other maizeinfecting viruses, with the tombusvirids having very few seedtransmitted viruses (Sastry 2013b). Transmission of other viruses in maize via seed at low levels has been reported for MDMV, with one seed transmission in 22,189 seedlings (Mikel et al. 1984), and no transmission of SCMV in 480 seedlings of seeds from inbred lines infected with SCMV in Kenya (Kitira 2018); transmission of high plains virus in sweet corn was three out of 38,473 seedlings tested (Forster et al. 2001). In contrast, examples of high seed-transmission rates for viruses include $30 \%$ by soybean mosaic virus (Domier et al. 2007), 25.3\% for bean common mosaic virus in bean cultivars (Mandour et al. 2013), and $46.6 \%$ transmission of dolichos yellow mosaic virus in lablab bean (Suruthi et al. 2018). Seed transmission of viruses is influenced by many factors, including the host and cultivar, the isolate, environmental conditions, and timing of infection (Sastry 2013a; Simmons and Munkvold 2014). Despite no transmission detected for SCMV in Kenya (Kitira 2018), Li et al. (2007) reported 91 positive seed-transmitted cases out of 1,193 seedlings for SCMV.

Most seed transmission of viruses involves the presence of virus in the embryo, leading to transmission of viruses to the next progeny (Sastry 2013a). Cytoplasmic connections lead to more embryo infections and to higher transmission of viruses from the seed; legumes have more cytoplasmic connections compared with maize and, thus, have more seed-transmitted viruses (Sastry 2013a). The level of seed contamination may not be correlated to the rate of seed transmission (Dombrovsky and Smith 2017), as in the present study, in which we found lower seed transmission in seed lots with higher seed contamination of MCMV and vice versa. The results are similar to findings with varying levels of contamination by cowpea aphid borne mosaic virus (CABMV). Increasing seed contamination levels at 0, 0.25, and $1 \%$ did not lead to an increase in the incidence of virus in 31-day-old cowpea seedlings of cultivars with low ability to transmit virus via seed (Néya et al. 2007). However, there was an increase in incidence when the contamination rate was $5 \%$, and there was no significant difference in the incidence of the virus when cultivars with high ability to transmit CABMV via seed were used. The presence of viruses on the seed coat or in the endosperm is common for most viruses, but if the virus is absent from the embryo, infection in seedlings was found to be rare (Johansen et al. 1994). The cultivars used in the present study are all highly susceptible to MCMV/MLN infection, except DK777, which is tolerant to MLN. The exact factors contributing to transmission of MCMV, even at extremely low rates, from contaminated seed to grow-out seedlings are still unknown. However, for some viruses it is possible for virus found on seed extract to infect seedlings, such as pepino mosaic virus infection of tomato and Nicotiana benthamiana seedlings (Ling 2008).

\section{Conclusions}

Maize is grown extensively in Kenya. Even less than $0.1 \%$ seed transmission rate of MCMV, if not properly detected and controlled, could have significant implications. The seeding rate for maize in Kenya is about 55,000 seeds per hectare; thus, a seed transmission rate of $0.1 \%$ would mean about 55 MCMVinfected plants per hectare. These infected plants, if not detected in time and discarded, could serve as a source of MCMV inoculum. Further, favorable weather conditions and the presence of MCMV vectors, especially the corn thrips that are widely prevalent in Kenya (Mahuku et al. 2015), could translate into significant infection across the field and ultimately decreased crop yield.

Understanding the probable reasons and the effects of different levels of contamination of maize seed by MCMV, and the implications of such contamination to the next-generation seedlings grown especially by the farmers, is important for effective management of MLN. Despite the very low seed transmission rate observed for MCMV recorded in the present study, the implications of maize seed contamination by MCMV are still significant. Therefore, effective and continued implementation of various management options and continued implementation of phytosanitary measures in production of seeds that are free from viruses causing MLN are critical to reduce the spread and impact of MLN and overall to improve the production of maize. 


\section{Acknowledgments}

This work was supported, in part, by the Bill \& Melinda Gates Foundation (grant number: INV-006697/OPP1138693), project name "Understanding and Preventing Seed Transmission of Maize Lethal Necrosis (MLN) in Africa". Under the grant conditions of the Foundation, a Creative Commons Attribution 4.0 Generic License has already been assigned to the Author Accepted Manuscript version that might arise from this submission. The work is also financially supported by the CGIAR Research Program on Maize (MAIZE). MAIZE receives W1\&W2 support from the Governments of Australia, Belgium, Canada, China, France, India, Japan, Korea, Mexico, Netherlands, New Zealand, Norway, Sweden, Switzerland, the United Kingdom, the United States, and the World Bank. We also acknowledge Derrick A. Mayfield, who assisted with the laboratory activities at the Seed Science Center, Iowa State University. Henry Onzere and George Mosota provided immense support during planting of the seeds, harvesting, and grinding of leaf and seed samples at KALRO-Kabete.

\section{Literature Cited}

Adams, I. P., Harju, V. A., Hodges, T., Hany, U., Skelton, A., Rai, S., Deka, M. K., Smith, J., Fox, A., Uzayisenga, B., Ngaboyisonga, C., Uwumukiza, B., Rutikanga, A., Rutherford, M., Ricthis, B., Phiri, N., and Boonham, N. 2014. First report of maize lethal necrosis disease in Rwanda. New Dis. Rep. 29:22.

Adams, I. P., Miano, D. W., Kinyua, Z. M., Wangai, A., Kimani, E., Phiri, N., Reeder, R., Harju, V., Glover, R., Hany, U., Souza-Richards, R., Deb Nath, P., Nixon, T., Fox, A., Barnes, A., Smith, J., Skelton, A., Thwaites, R., Mumford, R., and Boonham, N. 2013. Use of next-generation sequencing for the identification and characterization of Maize chlorotic mottle virus and Sugarcane mosaic virus causing maize lethal necrosis in Kenya. Plant Pathol. 62:741-749.

Albrechtsen, S. E. 2006a. Group testing of seeds. Pages 231-234 in: Testing Methods for Seed-Transmitted Viruses: Principles and Protocols. CABI Publishing, Wallingford, U.K.

Albrechtsen, S. E. 2006b. Seed transmission of viruses. Page 13 in: Testing Methods for Seed-Transmitted Viruses: Principles and Protocols. CABI Publishing, Wallingford, U.K.

Bernardo, P., Redinbaugh, M. G., and Barriball, K. 2018. Understanding Maize chlorotic mottle virus transmission through seed: Localization and infectivity. (Abstr.) Phytopathology 108:S1.245.

Bockelman, D. L., Claflin, L. E., and Uyemoto, J. K. 1982. Host range and seed transmission studies of maize chlorotic mottle virus in grasses and corn. Plant Dis. 66:216-218.

Cabanas, D., Watanabe, S., Higashi, C. H. V., and Bressan, A. 2013. Dissecting the mode of maize chlorotic mottle virus transmission (Tombusviridae: Machlomovirus) by Frankliniella williamsi (Thysanoptera: Thripidae). J. Econ. Entomol. 106:16-24.

Chen, C. L., and Swallow, W. H. 1990. Using group testing to estimate a proportion, and to test the binomial model. Biometrics 46:1035-1046.

Crowley, N. C. 1957. Studies on seed transmission of plant virus diseases. Aust. J. Biol. Sci. 10:449-464

De Groote, H., Oloo, F., Tongruksawattana, S., and Das, B. 2016. Community-survey based assessment of the geographic distribution and impact of maize lethal necrosis (MLN) disease in Kenya. Crop Prot. 82: 30-35.

Dombrovsky, A., and Smith, E. 2017. Seed transmission of Tobamoviruses: Aspects of global disease distribution. In: Advances in Seed Biology. J. C. Jimenez-Lopez, ed. IntechOpen, London, U.K.

Domier, L. L., Steinlage, T. A., Hobbs, H. A., Wang, Y., Herrera-Rodriguez, G., Haudenshield, J. S., McCoppin, N. K., and Hartman, G. L. 2007. Similarities in seed and aphid transmission among Soybean mosaic virus isolates. Plant Dis. 91:546-550.

FAOSTAT. 2021. Maize production data for Kenya. Accessed 12 August 2021. http://www.fao.org/faostat/en/\#data/QCL.

Forster, R. L., Seifers, D. L., Strausbaugh, C. A., Jensen, S. G., Ball, E. M., and Harvey, T. L. 2001. Seed transmission of the High plains virus in sweet corn. Plant Dis. 85:696-699.

Goldberg, K.-B., and Brakke, M. K. 1987. Concentration of maize chlorotic mottle virus increased in mixed infection with maize dwarf mosaic virus, strain B. Phytopathology 77:162-167.

ISTA. 2016. Sampling. Pages 2i-2-40 in: International Rules for Seed Testing. International Seed Testing Association, Bassersdorf, Switzerland.

Jensen, S. G. 1985. Laboratory transmission of maize chlorotic mottle virus by three corn rootworms. Plant Dis. 69:864-868.
Jensen, S. G., Wysong, D. S., Ball, E. M., and Higley, P. M. 1991. Seed transmission of maize chlorotic mottle virus. Plant Dis. 75:497-498.

Jiang, X. Q., Meinke, L. J., Wright, R. J., Wilkinson, D. R., and Campbell, J. E. 1992. Maize chlorotic mottle virus in Hawaiian-grown maize: Vector relations, host range and associated viruses. Crop Prot. 11:248-254.

Johansen, E., Edwards, M. C., and Hampton, R. O. 1994. Seed transmission of viruses: Current perspectives. Annu. Rev. Phytopathol. 32:363-386.

Kitira, F. G. 2018. Determining the role of seed and soil in the transmission of viruses causing maize lethal necrosis disease. M.Sc. thesis. University of Nairobi, Nairobi, Kenya.

KNBS. 2020. Economic Survey 2020. Kenya National Bureau of Statistics, Nairobi, Kenya.

Li, L., Wang, X., and Zhou, G. 2007. Analyses of maize embryo invasion by Sugarcane mosaic virus. Plant Sci. 172:131-138.

Ling, K.-S. 2008. Pepino mosaic virus on tomato seed: Virus location and mechanical transmission. Plant Dis. 92:1701-1705.

Liu, Z., Zhang, L., Yang, C., and Xia, X. 2016. Development of real-time reverse transcription PCR for detection of Maize chlorotic mottle virus based on a novel molecular marker. Cogent Food Agric. 2:1224047.

Mahuku, G., Lockhart, B. E., Wanjala, B., Jones, M. W., Kimunye, J. N., Stewart, L. R., Cassone, B. J., Sevgan, S., Nyasani, J. O., Kusia, E., Kumar, P. L., Niblett, C. L., Kiggundu, A., Asea, G., Pappu, H. R., Wangai, A., Prasanna, B. M., and Redinbaugh, M. G. 2015. Maize lethal necrosis (MLN), an emerging threat to maize-based food security in subSaharan Africa. Phytopathology 105:956-965.

Mandour, A. M., Abdelmaksoud, H. M. M., and El-Tahlawey, A. M. 2013. Seed transmission of bean common mosaic virus. Egypt. J. Agric. Res. 91:403-409.

Mikel, M. A., D'Arcy, C. J., and Ford, R. E. 1984. Seed transmission of maize dwarf mosaic virus in sweet corn. Phytopathol. Z. 110:185-191.

Monger, W. A., Seal, S., Cotton, S., and Foster, G. D. 2001. Identification of different isolates of Cassava brown streak virus and development of a diagnostic test. Plant Pathol. 50:768-775.

Nelson, S., Brewbaker, J., and Hu, J. 2011. Maize chlorotic mottle. Plant Dis. 79:1-6.

Néya, B. J., Zabré, J., Millogo, R. J., Ginko, S., and Konaté, G. 2007. Effect of cowpea seeds contamination rate by the Cowpea aphid borne mosaic virus. Pak. J. Biol. Sci. 10:4365-4374.

Prasanna, B. M., Suresh, L. M., Mwatuni, F., Beyene, Y., Makumbi, D., Gowda, M., Olsen, M., Hodson, D., Worku, M., Mezzalama, M., Molnar, T., Dhugga, K. S., Wangai, A., Gichuru, L., Angwenyi, S., Alemayehu, Y., Grønbech Hansen, J., and Lassen, P. 2020. Maize lethal necrosis (MLN): Efforts toward containing the spread and impact of a devastating transboundary disease in sub-Saharan Africa. Virus Res. 282:197943.

Ranum, P., Peña-Rosas, J. P., and Garcia-Casal, M. N. 2014. Global maize production, utilization, and consumption. Ann. N. Y. Acad. Sci. 1312:105112.

Redinbaugh, M. G., and Stewart, L. R. 2018. Maize lethal necrosis: An emerging, synergistic viral disease. Annu. Rev. Virol. 5:301-322.

Sastry, K. S. 2013a. Mechanism of seed transmission. Pages 85-95 in: Plant Virus and Viroid Diseases in the Tropics. Springer, Dordrecht, The Netherlands.

Sastry, K. S. 2013b. Identification and taxonomic groups, Pages 55-58 in: Seed-Borne Plant Virus Diseases. Springer, Dordrecht, The Netherlands.

Sergeant, E. S. G. 2018. Epitools Epidemiological calculators. https:// epitools.ausvet.com.au/.

Shango, P., Onyango, C., Oganda, J. K., Macharia, I., and Kariuki, G. 2019. Seed certification as a means of curbing emerging diseases: A case study of maize lethal necrosis disease in Kenya. J. Agric. Res. Adv. 1: 39-43.

Simmons, H., and Munkvold, G. 2014. Seed transmission in the Potyviridae, Pages 3-15 in: Global Perspectives on the Health of Seeds and Plant Propagation Material.

Stewart, L. R., Willie, K., Wijeratne, S., Redinbaugh, M. G., Massawe, D., Niblett, C. L., Kiggundu, A., and Asiimwe, T. 2017. Johnsongrass mosaic virus contributes to maize lethal necrosis in East Africa. Plant Dis. 101: 1455-1462.

Sui, X., Li, R., Shamimuzzaman, M., Wu, Z., and Ling, K.-S. 2019. Understanding the transmissibility of cucumber green mottle mosaic virus in watermelon seeds and seed health assays. Plant Dis. 103:1126-1131.

Suruthi, V., Nakkeeran, S., Renukadevi, P., Malathi, V. G., and Rajasree, V. 2018. Evidence of seed transmission of dolichos yellow mosaic virus, a begomovirus infecting lablab-bean in India. VirusDis. 29:506-512.

Uyemoto, J. K., Bockelman, D. L., and Claflin, L. E. 1980. Severe outbreak of corn lethal necrosis disease in Kansas. Plant Dis. 64:99-100. 
Wamaitha, M. J., Nigam, D., Maina, S., Stomeo, F., Wangai, A., Njuguna, J. N., Holton, T. A., Wanjala, B. W., Wamalwa, M., Lucas, T., Djikeng, A., and Garcia-Ruiz, H. 2018. Metagenomic analysis of viruses associated with maize lethal necrosis in Kenya. Virol. J. 15:90.

Wangai, A. W., Redinbaugh, M. G., Kinyua, Z. M., Miano, D. W., Leley,

P. K., Kasina, M., Mahuku, G., Scheets, K., and Jeffers, D. 2012. First report of Maize chlorotic mottle virus and maize lethal necrosis in Kenya. Plant Dis. 96:1582.

Wu, H. J., Qin, B. X., Chen, H. Y., Peng, B., Cai, J. H., and Gu, Q. S. 2010. The rate of seed contamination and transmission of cucumber green mottle mosaic virus in watermelon and melon. Sci. Agric. Sin. 44:15271532. 